\title{
PENGARUH INDEKS SSEC, N225, STI, DAN FAKTOR MAKROEKONOMI TERHADAP IHSG
}

\author{
Sebtian Dwi Prahesti \\ Universitas Negeri Surabaya \\ sebtianprahesti16080574081@mhs.unesa.ac.id \\ R.A. Sista Paramita \\ Universitas Negeri Surabaya \\ sistaparamita@unesa.ac.id
}

\begin{abstract}
This study is to determine the effect of the exchange rate, inflation, the money supply, BI Rate, The Fed, SSEC (Shanghai Stock Exchange Composite Index), N225 (Nikkei 225), and STI (Strait Time Index) on the Composite Stock Price Index. The dependent variable is the CSPI $(Y)$ and the independent variable of macroeconomic factors namely the exchange rate (X1), inflation (X2), money supply (X3), and BI Rate (X4), The Fed (X5), and the global index such as SSEC (X6), Nikkei 225 (X7), and STI (X8). This study implements multiple linear regression analysis methods of Statistical Package for Social Science. This study indicates that the exchange rate and the Strait Time Index influence the Composite Stock Price Index, while the inflation variable, the money supply, BI Rate, The Fed interest rate, the SSEC, and the Nikkei 225 don't affect the CSPI (Composite Stock Price Index). Inflation doesn't affect the CSPI because inflation in the research period is still relatively mild. The money supply doesn't affect the CSPI because people tend to use their money to invest in the money market rather than investing in shares. The BI rate doesn't affect CSPI because the BI Rate is not a parameter for investors in investing. The Fed doesn't affect CSPI because investors do not use The Fed Rate as a benchmark in investing. SSEC and N225 index don't affect the CSPI due to other factors outside the economy that affect the movement of the index.
\end{abstract}

Keywords: CSPI; exchange rate; STI.

\section{PENDAHULUAN}

Pasar modal merupakan sarana suatu perusahaan dalam memperoleh sumber dana untuk kegiatan operasional perusahaannya. Saham merupakan jenis investasi pasar modal yang diminati masyarakat karena dengan modal kecil dapat menikmati keuntungan (Samsul, 2015:185). Menurut Samsul (2015:35) indeks IHSG (Indeks Harga Saham Gabungan) digunakan para investor sebagai pedoman dalam memprediksi dan mengetahui bagaimana perkembangan pasar modal Indonesia. Peningkatan atas pasar modal (bullish) atau penurunan (bearish) dapat ditinjau dari kenaikan dan penurunan keseluruhan harga saham yang tampak melalui pergerakan IHSG. SSEC (Shanghai Stock Composite Index) merupakan indeks harga saham yang memperdagangkan seluruh jenis saham di pasar Cina. Indeks N225 (Nikkei 225) merupakan indeks keseluruhan harga saham yang diperjual belikan di negara Jepang, sedangkan STI (Strait Time Index) merupakan indeks yang mencerminkan keseluruhan harga saham yang diperdagangkan di negara Singapura. Gambar 1 menunjukkan bahwa IHSG bergerak naik turun sesuai dengan keadaan ekonomi, pengaruh pertumbuhan ekonomi luar negeri serta pengaruh dari dalam negeri dan aksi jual/ beli para investor asing maupun dalam negeri. Dari ketiga indeks yang tertera dalam gambar, sekilas dapat terlihat bahwa indeks SSEC, IHSG, N225, dan STI bergerak hampir sama, apabila SSEC naik, IHSG, N225 dan STI juga naik, dan sebaliknya.

Beberapa penelitian memberikan jawaban berbeda dengan terkait pernyataan di atas. Riset oleh Subiantoro et al. (2018), dan Triyono et al. (2016) menyatakan bahwa SSEC non signifikan terhadap IHSG, dan riset yang dilakukan Sari \& Purwohandoko (2019) menyatakan IHSG tidak dipengaruhi oleh indeks Nikkei 225. Serta hasil riset oleh Desfiandi et al. (2017), Lailia et al. (2014), Tarigan et al. (2015), dan Triyono et al. (2016) memberikan hasil bahwa Strait Time Index memberikan pengaruh yang positif kepada IHSG, namun hasil riset oleh Pamungkas \& Darmawan (2018) menemukan bahwa indeks STI memengaruhi secara negatif terhadap IHSG, serta riset oleh Candradewi \& Yasa (2018) menemukan bahwa indeks STI tidak memberikan pengaruh apapun terhadap IHSG. Pergerakan indeks 
yang cenderung hampir sama namun dari berbagai penelitian terdahulu terdapat hasil ketika menggunakan indeks saham global seperti indeks SSEC, indeks Nikkei 225 dan indeks STI dalam memengaruhi Indeks Harga Saham Gabungan. Mengingat letak negara Cina, Jepang dan Singapura berdekatan dengan negara Indonesia, sehingga kegiatan ekspor dan impor terjalin sangat kuat, hubungan perekonomian ini dapat memengaruhi pasar modal Indonesia.

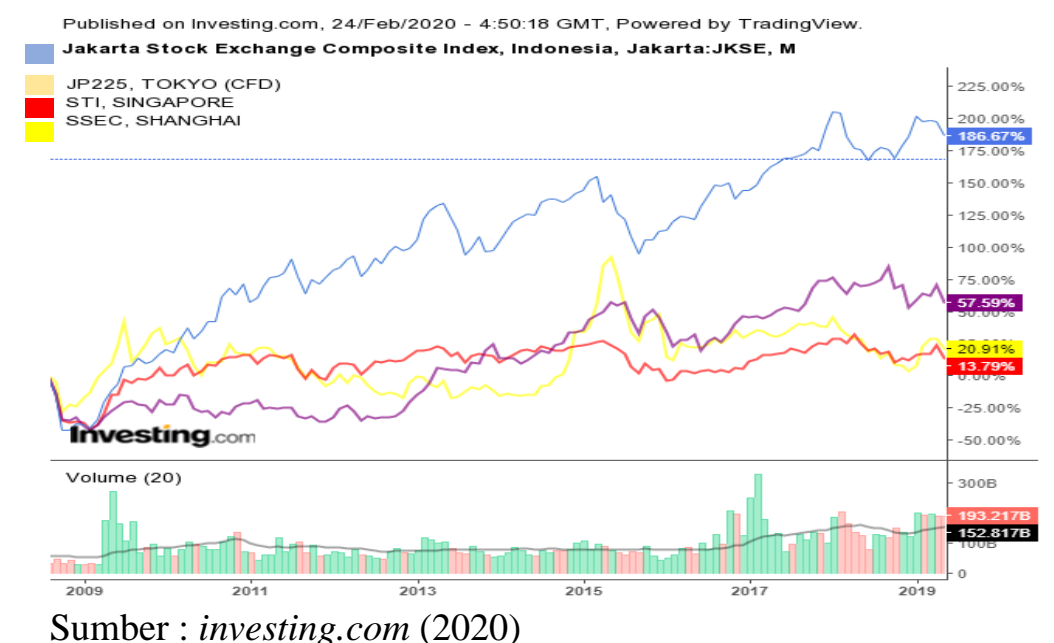

Gambar 1. GRAFIK INDEKS IHSG, N225, SSEC DAN STI

Menurut Jogiyanto (2000:29), suatu pengumuman akan menjadi informasi baru bagi seorang investor dan tanda sebagai sinyal dalam melakukan keputusan atas investasi. Jika informasi tersebut memberikan hal yang baik, maka investor akan melakukan reaksi positif atas pasar pada waktu pengunguman tersebut. Perubahan faktor makroekonomi akan lebih cepat bereaksi terhadap harga saham, karena apabila pergantian itu terjadi, investor akan mengetahaui dan menghitung dampaknya pada masa yang akan datang, dan membeli saham atau menjual saham yang bersangkutan. Beberapa faktor makroekonomi yang dapat memengaruhi pergerakan IHSG meliputi kurs, inflasi, jumlah uang beredar, BI Rate, dan The Fed.

Menurut Tandelilin (2008:214), peningkatan nilai mata uang rupiah terhadap asing adalah hal yang baik baik seorang investor. Pada saat mata uang rupiah rupiah menguat, dampak yang terjadi adalah kepercayaan investor semakin meningkat dan mereka akan memilih instrumen saham untuk berinvestasi. Apabila mata uang rupiah terdepresiasi, akan mengakibatkan kenaikan harga impor dan peningkatan biaya emiten yang menggunakan bahan baku impor yang dapat berakibat menurunnya pendapatan dan keuntungan perusahaan. Penurunan pendapatan juga mengakibatkan menurunnya laba, sehingga investor tidak tertarik melakukan investasi saham pada perusahaan itu. Kejadian ini akan memberikan efek pada penurunan IHSG. Menurut Syarif \& Asandimitra (2015), penelitiannya memberikan hasil bahwa kurs memberikan dampak negatif terhadap IHSG, sedangkan Zabidi \& Asandimitra (2018) pada hasil risetnya mmberikan hasil bahwa kurs tidak memberikan pengaruh apapun terhadap IHSG. Riset yang telah dilakukan Adanti (2017), Wismantara \& Darmayanti (2017) memberikan hasil nilai kurs berpengaruh positif pada IHSG.

Peningkatan inflasi juga dapat menaikkan biaya dan pendapatan perusahaan. Apabila pendapatan total emiten lebih rendah dari keseluruhan jumlah yang dikeluarkan, maka keuntungan emiten akan mendapatkan laba yang lebih sedikit. Adanya penurunan keuntungan perusahaan mengakibatkan dividen yang diberikan akan menurun, sehingga investor kurang berminat melakukan investasi di instrumen saham yang ditawarkan perusahaan sehingga berakibat pula pada turunnya nilai IHSG (Syarif \& Asandimitra, 2015). Berdasarkan penelitian yang dilakukan Sari \& Purwohandoko (2019), Syarif \& Asandimitra (2015), Zabidi \& Asandimitra (2018), perubahan inflasi tidak memberikan pengaruh kepada IHSG. Studi oleh Triyono et al. (2016) memberikan hasil bahwa inflasi memberi pengaruh yang signifikan negatif terhadap IHSG. Serta hasil riset yang dilakukan oleh Sukamto (2016), Taufiq \& Kefi (2015) menyatakan inflasi memberikan hasil yang signifikan positif terhadap IHSG. 
Sebtian Dwi Prahesti \& R.A. Sista Paramita. Pengaruh Indeks SSEC, N225, STI, dan Faktor Makroekonomi terhadap IHSG

BI Rate merupakan kebijakan Bank Indonesia menentukan nilai besaran suku bunga, yang akan menjadi pedoman bagi penetapan bunga pada bank di Indonesia, jika nilai suku bunga meningkat, investor menarik sahamnya dan memindahkannya ke tabungan, sebaliknya apabila suku bunga turun, investor akan menyimpan dananya pada instrumen saham (Adanti, 2017). Menurut Tandelilin (2008:48) mengatakan jika adanya perubahan suku bunga bisa memberi dampak secara berbalik arah, ceteris paribus harga saham. Artinya apabila suku bunga meningkat, dampaknya harga saham akan turun, serta sebaliknya. Riset yang telah dilakukan oleh Wismantara \& Darmayanti (2017) menyatakan nilai suku bunga memberikan dampak positif terhadap IHSG, sedangkan Yustisia (2016) memberikan hasil bahwa IHSG memengaruhi secara negatif terhadap IHSG, menurut Triyono et al. (2016) hasil penelitiannya mengungkapkan bahwa suku bunga tidak memberikan dampak apapun terhadap IHSG.

Suku bunga The Fed merupakan pedoman suku bunga bagi bank komersial Amerika Serikat, sehingga kenaikan maupun penurunannya membawa dampak bagi perekonomian internasional, hal ini dikarenakan dolar AS diterima dunia sebagai mata uang global, saat ini transaksi internasional dilakukan menggunakan mata uang dolar AS. Amerika Serikat adalah negara maju dengan skala perekonomian negaranya yang besar di dunia, sehingga kebijakan The Fed akan membuat investor menyimpan dananya di Amerika Serikat, maka diperlukan adanya riset apakah suku bunga The Fed dapat memengaruhi IHSG (Syarif \& Asandimitra, 2015). Penelitian oleh Syarif \& Asandimitra (2015) memberikan hasil bahwa The Fed tidak memberikan pengaruh kepada IHSG, sedangkan studi oleh Misgayanti \& Zuhroh (2009) menyatakan suku bunga The Fed berpengaruh negatif kepada IHSG. Namun riset oleh Miyanti \& Wiagustini (2018) memberikan hasil The Fed memberikan pengaruh positif terhadap IHSG.

Penelitian ini bertujuan untuk menganalisis pengaruh indeks saham SSEC, N225 dan STI serta faktor makroekonomi terhadap Indeks Harga Saham Gabungan.

\section{KAJIAN PUSTAKA DAN PENGEMBANGAN HIPOTESIS}

\section{Contagion Effect Theory}

Teori Contagion atau dampak menular merupakan suatu kejadian apabila terjadi krisis, dapat mengakibatkan dampak buruk pada negara lainnya dan akan mengakibatkan pelemahan perekonomian. Dampaknya dapat memberikan pengaruh yang relatif dan tidak sama imbasnya bagi negara lain, tergantung kepada seberapa besar kerja sama internasional di bidang ekonomi pada negara lain (Zabidi \& Asandimitra, 2018).

\section{Random Walk Theory}

Teori Random Walk merupakan teori menjelaskan bahwa harga saham dapat berganti secara acak (random) dan tidak dapat diketahui nilainya dimasa yang akan datang. Perubahan yang random ini dapat terjadi karena adanya informasi yang diperoleh investor, tergantung pada reaksi pasar atas adanya informasi yang telah terpublikasikan tersebut, Teori ini telah diajukan secara resmi oleh Maurice Kendall dalam makalahnya tahun 1953 yang berjudul The Analytics of Economic Time Series (Samsul, 2015:269). Apabila suatu informasi itu sudah diketahui maka disebut informasi sekarang dan akan memengaruhi harga saham saat ini dengan cepat. Tidak ada jaminan atas kebenaran prediksi harga saham yang sebenarnya dikemudian hari, informasi yang dianggap buruk (bad news) seperti kenaikan tingkat inflasi, kenaikan tingkat bunga bank, dan berita lainnya yang akan memberikan dampak negatif terhadap harga saham. Sedangkan berita baik (good news) seperti menurunnya tingkat suku bunga The Fed, dan lain-lain (Samsul, 2015:202).

\section{Indeks Harga Saham Gabungan (Y)}

Data indeks yang dipergunakan pada riset merupakan data hasil perhitungan perubahan harga closing price IHSG mulai bulan Januari 2009 hingga bulan Desember 2019. Penelitian ini menggunakan harga penutupan karena harga tersebut merupakan data harga terakhir pada bulan yang bersangkutan. Pada riset ini IHSG dihitung menggunakan rumus perubahan yang dapat dilihat di rumus (1) (Zabidi \& Asandimitra, 2018). 
$I H S G=\frac{I H S G_{t}-I H S G_{t-1}}{I H S G_{t-1}}$

Keterangan :

$\mathrm{IHSG}_{\mathrm{t}}=\mathrm{IHSG}_{\mathrm{H}}$ periode $\mathrm{t}_{\mathrm{t}}$

$\mathrm{IHSG}_{\mathrm{t}-1}=\mathrm{IHSG}_{\text {periode }} \mathrm{t}-1$

\section{$\operatorname{Kurs}\left(\mathbf{X}_{1}\right)$}

Data kurs pada riset merupakan nilai perubahan kurs rupiah terhadap dollar pada periode mulai dari bulan Januari 2009 hingga pada bulan Desember 2019. Rumus perubahannya dapat dilihat di rumus (2) (Zabidi \& Asandimitra, 2018).

Kurs $=\frac{\text { Kurs }_{t}-\text { Kurs }_{t-1}}{\text { Kurs tengah }_{t-1}} \times 100 \%$

Keterangan:

Kurs tengah ${ }_{\mathrm{t}}=$ kurs tengah periode $_{\mathrm{t}}$

Kurs tengah $\mathrm{t}_{\mathrm{t}-1}=$ kurs tengah periode $_{\mathrm{t}-1}$

\section{Inflasi $\left(\mathbf{X}_{2}\right)$}

Data inflasi yang dipergunakan pada penelitian ini merupakan perubahan IHK bulan Januari 2009 sampai bulan Desember 2019. Dengan rumus perubahan yang dapat dilihat di rumus (3) (Zabidi \& Asandimitra, 2018).

$$
\text { Inflasi }=\frac{I H K_{t}-I H K_{t-1}}{I H K_{t-1}} \times 100 \%
$$

Keterangan:

$\mathrm{IHK}_{\mathrm{t}}=$ Indeks Harga Konsumen periode ${ }_{\mathrm{t}}$

$\mathrm{IHK}_{\mathrm{t}-1}=$ Indeks Harga Konsumen periode $\mathrm{t}_{\mathrm{t}-1}$

\section{Jumlah Uang Beredar $\left(\mathbf{X}_{3}\right)$}

Penelitian ini menggunakan M2 yang menurut Samsul (2015:210), terdiri dari uang giral, uang kartal, credit deposit, demand deposit, credit overdraft, traveller's check issued by nonbank dan rekening giro mutual funds, money market, Eurodollar deposit, overnight Repos, time deposit di bawah US\$100.000. Data yang digunakan pada riset ini adalah perubahan JUB bulan Januari 2009 sampai bulan Desember 2019.Rumus perubahan dapat dilihat di rumus (4) (Kusumawati \& Asandimitra, 2017).

$J U B=\frac{J U B_{t}-J U B_{t-1}}{J U B_{t-1}} \times 100 \%$

Keterangan :

$\mathrm{JUB}_{\mathrm{t}}=\mathrm{Jumlah}_{\mathrm{a}}$ uang beredar periode $\mathrm{t}_{\mathrm{t}}$

$\mathrm{JUB}_{\mathrm{t}-1}=\mathrm{Jumlah}$ uang beredar periode $\mathrm{t}-1$

\section{BI Rate $\left(\mathbf{X}_{4}\right)$}

Data BI Rate pada riset ini adalah BI Rate bulanan Januari 2009 sampai bulan Desember 2019.

\section{The Fed $\left(\mathbf{X}_{5}\right)$}

Data The Fed pada riset mengambil data aktual The Fed. Data yang dipakai untuk diteliti merupakan data akhir bulan, mulai bulan Januari 2009 sampai bulan Desember 2019.

\section{$\operatorname{SSEC}\left(\mathbf{X}_{6}\right)$}

Data indeks SSEC pada riset ini adalah hasil perhitungan perubahan indeks SSEC. Data yang dipakai merupakan data bulanan indeks SSEC dari Januari 2009 - Desember 2019. Dengan rumus mengacu pada perubahan indeks Nikkei 225, yang dapat dilihat di rumus (5) (Zabidi \& Asandimitra, 2018). 
Sebtian Dwi Prahesti \& R.A. Sista Paramita. Pengaruh Indeks SSEC, N225, STI, dan Faktor Makroekonomi terhadap IHSG

$S S E C=\frac{S S E C_{t}-S S E C_{t-1}}{S S E C_{t-1}} \times 100 \%$

Keterangan :

$\mathrm{SSEC}_{\mathrm{t}}=$ Indeks SSEC periode $_{\mathrm{t}}$

SSEC $_{\mathrm{t}-1}=$ Indeks SSEC periode $_{\mathrm{t}-1}$

Nikkei $225\left(\mathrm{X}_{7}\right)$

Data indeks Nikkei 225 diperoleh dari hasil perhitungan perubahan indeks Nikkei 225. Data yang dipakai untuk riset adalah data bulanan indeks Nikkei 225 dari Januari 2009-Desember 2019. Dengan rumus perubahan yang dapat dilihat di rumus (6) (Zabidi \& Asandimitra, 2018).

$N i k k e i=\frac{\text { Nikkei }_{t}-\text { Nikkei }_{t-1}}{\text { Nikkei }_{t-1}}$

Keterangan :

Nikkei $_{\mathrm{t}}=$ Indeks Nikkei 225 periode $_{\mathrm{t}}$

Nikkei $_{t-1}=$ Indeks Nikkei 225 periode $_{t-1}$

Strait Times Index $\left(\mathbf{X}_{8}\right)$

Pengukuran indeks Strait Times dengan menghitung perubahan indeks Strait Times. Data untuk riset merupakan data bulanan indeks Strait Times dari Januari 2009 - Desember 2019. Denga rumus perubahan yang mengacu pada rumus indeks sebelumnya oleh Zabidi \& Asandimitra (2018) yang dapat dilihat di rumus (7).

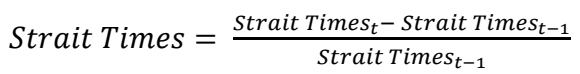

Keterangan:

Strait Times $\mathrm{s}_{\mathrm{t}}=$ Indeks Strait Times periode $\mathrm{t}_{\mathrm{t}}$

Strait Times $_{\mathrm{t}-1}=$ Indeks Strait Times periode $_{\mathrm{t}-1}$

\section{Hubungan antar Variabel}

Menurut Samsul (2015:202) Peningkatan kurs secara drastis akan berdampak buruk pada emiten yang mempunyai utang dalam satuan dollar, padahal produknya yang dihasilkan hanya dijual ada di dalam negeri. Namun jika emiten merupakan penghasil ekspor, maka akan mendapatkan keuntungan atas kenaikan kurs. Beberapa emiten yang tercatat pada Bursa Efek Indonesia mendapatkan efek buruk dan baik atas perubahan kurs tersebut dan akan berdampak pada IHSG tergantung pada kelompok yang lebih dominan mendapatkan pengaruh apakah positif atau negatif. Hasil riset Syarif \& Asandimitra (2015) menerangkan bahwa kurs memengaruhi negatif terhadap IHSG, hal ini terjadi karena apabila kurs rupiah terhadap dolar mengalami depresiasi, bagi investor sendiri menunjukkan situasi fundamental perekonomian Indonesia dalam kondisi kurang baik. Ketika prospek perekonomian kurang baik, investor cenderung melepaskan saham-saham yang dimilikinya untuk menghindari risiko. Kemudian riset yang dilakukan oleh Adanti (2017) memberikan hasil kurs berpengaruh positif kepada IHSG, Hal ini sesuai dengan teori portofolio balance yang dikemukakan oleh Granger, bahwa hubungan antara kurs dan harga saham adalah positif. Hal ini berarti pada saat Dollar AS terapresiasi dan kurs rupiah terdepresiasi maka IHSG di BEI akan turun, begitu pula sebaliknya. Sedangkan penelitian oleh Zabidi \& Asandimitra (2018) memberikan hasil bahwa kurs tidak memengaruhi pergerakan IHSG, hal ini disebabkan pada periode penelitian investor di pasar modal tidak terlalu mempedulikan kurs sehingga tidak memengaruhi IHSG.

H1: Kurs berpengaruh terhadap IHSG pada periode 2009-2019.

Inflasi yang terlalu tinggi dapat menyebabkan dampak negatif pada perekonomian, beberapa perusahaan akan mengalami kebangkrutan atas biaya bahan baku yang terlalu tinggi. Inflasi yang meningkat drastis memengaruhi pada harga saham suatu negara (Samsul, 2015:201). Hasil riset 
Wismantara \& Darmayanti (2017) memberikan hasil bahwa inflasi memengaruhi secara negatif kepada IHSG, hal ini dikarenakan kenaikkan inflasi menjadi sinyal negatif bagi investor untuk berinvestasi di pasar modal dan cenderung melepaskan saham untuk beralih pada investasi pada bentuk lain seperti tabungan atau deposito. Peralihan investasi ke bentuk yang lain akan menyebabkan investor untuk melakukan penjualan saham. Namun riset oleh Sukamto (2016) memberikan hasil inflasi memengaruhi secara positif kepada IHSG. Hal ini disebabkan karena melihat parah tidaknya inflasi yang terjadi, apabila inflasi ringan maka akan berampak positif bagi perekonomian dan sebaliknya apabila inflasi tinggi (hyperinflasi) maka akan berdampak negatif. Keadaan fundamental ekonomi dalam negeri yang stabil juga memberikan dampak positif terhadap IHSG. Namun riset oleh Desfiandi et al. (2017) memberikan hasil bahwa inflasi tidak memberikan pengaruh kepada pergerakan IHSG. Hal ini karena inflasi ringan (di bawah angka 10\%) tidak mampu memengaruhi pasar modal. Inflasi yang ringan tidak begitu mengganggu perekonomian Indonesia, dengan begitu tingkat inflasi ini tidak secara langsung memengaruhi keputusan investor untuk melakukan investasi dalam bentuk saham pada Bursa Efek Indonesia.

\section{H2: Inflasi berpengaruh terhadap IHSG pada periode 2009-2019.}

Apabila jumlah uang beredar meningkat, terjadi penurunan suku bunga dan terjadi peningkatan harga saham, sehingga pasar menjadi bullish (Samsul, 2015:210). Informasi peningkatan JUB merupakan pertanda apabila jika uang spekulatif masyarakat meningkat dan dianggap oleh investor sebagai good news, maka investor akan menyimpan dananya pada instrumen saham. Riset yang dilakukan oleh Otorima \& Kesuma (2016) memberikan hasil bahwa JUB memengaruhi IHSG secara negatif, hal ini dikarenakan peningkatan jumlah uang beredar menadakan bahwa daya beli masyarakat menurun, sehingga menyebabkan pendapatan perusahaan menurun dan berpengaruh pada penurunan IHSG. Namun riset oleh Siregar et al. (2014) memberikan hasil bahwa JUB memengaruhi secara positif kepada IHSG dan menjelaskan apabila JUB naik $1 \%$ maka IHSG akan mengalami peningkatan sebesar $1,385 \%$. Dengan meningkatnya jumlah uang beredar menandakan masyarakat menyimpan kelebihan uangnya pada instrimen saham, sehingga apabila JUB meningkat, IHSG akan mengalami peningkatan. Sedangkan riset oleh Wibowo et al. (2016) memberikan hasil bahwa IHSG tidak dipegaruhi oleh JUB. Pernyataan ini disebabkan karena Masyarakat cenderung menggunakan uangnya untuk alat pembayaran atas kebutuhan konsumsi, dalam transaksi pembelian atau membayar hutang, dan melakukan investasi di pasar uang daripada berinvestasi di saham.

H3: Jumlah uang beredar berpengaruh terhadap IHSG pada periode 2009-2019.

Berita tentang kenaikan suku bunga BI Rate akan memengaruhi secara negatif pada pasar modal, karena investor akan menyimpan dananya pada bank untuk mendapatkan keuntungan bunga serta risiko yang lebih rendah, akibatnya harga saham menjadi turun (Sukamto, 2016). Menurut Samsul (2015:201) emiten juga akan terkena dampak negatif atas kenaikan tingkat bunga pinjaman, yang menyebabkan beban kredit usahanya semakin meningkat sehingga akan berdampak secara langsung pada perolehan laba perusahaan. Penurunan laba perusahaan juga berdampak pada laba yang dibagikan kepada investor, sehingga investor lebih memilih menarik sahamnya dan berakibat pada penurunan IHSG. Riset yang telah dilakukan oleh Subiantoro et al. (2018) memberikan hasil bahwa BI Rate memberikan pengaruh secara negatif terhadap IHSG. Hal ini karena tingkat suku bunga BI rate merupakan instrument investasi rendah resiko sehingga apabila tingkat suku bunga tinggi akan menarik bagi investor memindahkan portofolionya dari IHSG. Namun riset oleh Wismantara \& Darmayanti (2017) memberikan hasil bahwa BI Rate memengaruhi IHSG secara positif. Pernyataan ini disebabkan oleh ketika suku bunga naik maka akan berdampak pada perkembangan ekonomi yang membaik sehingga investor akan tertarik untuk berinvetasi di pasar modal dan gencarnya pemerintah untuk menarik investor agar menabung di saham atau pasar modal. Sedangkan riset oleh Triyono et al. (2016) memberikan hasil bahwa BI Rate tidak memberikan pengaruh terhadap IHSG. Hal ini dikarenakan investor dalam menanamkan modalnya tidak memperhatikan pergerakan suku bunga BI Rate.

H4: BI Rate berpengaruh terhadap IHSG pada periode 2009-2019. 
Sebtian Dwi Prahesti \& R.A. Sista Paramita. Pengaruh Indeks SSEC, N225, STI, dan Faktor Makroekonomi terhadap IHSG

McEachrn (2000:294) dalam Syarif \& Asandimitra (2015) menjelaskan The Fed adalah pedoman tingkat bunga pinjaman antar bank. Kenaikan The Fed dapat berpengaruh atas penarikan dana investor yang kemudian dipindahkan ke Amerika Serikat, begitu pula sebaliknya jika suku bunga The Fed mengalami penurunan. Riset oleh Syarif \& Asandimitra (2015) memberikan hasil The Fed tidak memengaruhi IHSG artinya masyarakat tidak memperhatikan suku bunga The Fed dalam berinvestasi. Sedangkan riset oleh Misgayanti \& Zuhroh (2009) memberikan hasil The Fed memberikan pengaruh secara negatif IHSG. Hal ini karena ketika The Fed meningkatkan suku bunga maka banyak uang yang terserap di Amerika, hal tersebut berakibat investasi di tabungan lebih menarik daripada investasi di saham. Namun riset oleh Miyanti \& Wiagustini (2018) memberikan hasil The Fed memberikan pengaruh positif terhadap IHSG. Pengaruh positif antara suku bunga The Fed terhadap harga saham terjadi karena kenaikan suku bunga The Fed sebesar $0,25 \%$ dinilai tidak terlalu signifikan oleh investor jika dibandingkan dengan peluang investasi di pasar saham Indonesia yang dinilai masih sangat menjanjikan yang ditunjang juga dengan pertumbuhan perekonomian Indonesia yang positif.

H5: The Fed berpengaruh terhadap IHSG pada periode 2009-2019.

Kenaikan indeks SSEC merupakan pertanda jika perekonomian Cina membaik, akan meningkatkan IHSG karena adanya peningkatan kegiatan ekspor dan impor yang membuat pasar modal di Indonesia meningkat. Selaras dengan teori contagion effect menjelaskan bahwa keadaan ekonomi suatu negara akan berakibat pada negara lain. Riset yang telah dilakukan oleh Tarigan et al. (2015) memberikan hasil bahwa indeks SSEC memberikan pengaruh secara negatif terhadap IHSG, karena perubahan indeks bursa saham di Indonesia atau IHSG selain dipengaruhi oleh bursa saham asing juga dipengaruhi oleh kondisi non ekonomi, seperti keamanan, politik, dan bencana alam, sehingga apabila SSEC menurun menyebabkan IHSG meningkat, dikarenakan kondisi perekonomian Indonesia menguat. Sedangkan riset yang dilakukan oleh Bery \& Worokinasih (2018) memberikan hasil SSEC memberikan pengaruh secara positif kepada IHSG, karena Indonesia dan Cina berada dalam satu kawasan regional Asia. Pengaruh positif yang ditunjukkan SSEC dapat terjadi karena kejadian dan dinamika harga di suatu bursa dapat memengaruhi bursa lain terutama dengan bursa saham dari negara-negara yang berdekatan. Kemudian riset oleh Subiantoro et al. (2018), dan Triyono et al. (2016) memberikan hasil indeks SSEC tidak memberikan pengaruh kepada IHSG. Pernyataan ini disebabkan pada periode penelitian terjadi penurunan keadaan ekonomi dan menurunnya indeks SSEC sebesar 35\% namun IHSG yang terus menguat didorong sentimen positif dalam negeri dan naiknya rating Indonesia menjadi negara layak investasi membuat IHSG menguat hingga menembus all time high di atas 6300 poin.

H6: Indeks SSEC berpengaruh terhadap IHSG pada periode 2009-2019.

Kenaikan indeks Nikkei 225 merupakan pertanda jika perekonomian Jepang membaik, akan meningkatkan IHSG karena adanya peningkatan kegiatan ekspor dan impor yang membuat pasar modal di Indonesia meningkat (Zabidi \& Asandimitra, 2018). Selaras dengan teori contagion effect menjelaskan bahwa keadaan ekonomi suatu negara akan berakibat pada negara lain. Riset yang telah dilakukan oleh Suprihati (2015) memberikan hasil bahwa indeks N225 memberikan pengaruh secara negatif terhadap IHSG, karena ketidakstabilan perekonomian Indonesia membuat investor tidak menanamkan sahamnya pada negara Indonesia, sehingga kenaikan indeks Nikkei 225 tidak mampu memengaruhi IHSG. Riset oleh Subiantoro et al. (2018) memberikan hasil indeks N225 memengaruhi secara positif kepada IHSG, hal ini terjadi karena indeks Nikkei 225 pada tahun 2015 tercatat menurun terdampak krisis pada indeks SSEC karena Cina merupakan mitra utama ekonomi Jepang. Pada 2016 seiring membaiknya kepercayaan investor dan perekonomian global indeks Nikkei 225 kembali menguat hingga akhir 2017 menembus rekor di atas 22000 poin. Hal tersebut sesuai dengan pergerakan IHSG di mana sempat melemah pada 2015 dikarenakan suku bunga yang tinggi namun menguat pada 2016 hingga 2017 seiring sentiment positif dari dalam dan luar negeri. Riset oleh Zabidi \& Asandimitra (2018) memberikan hasil N225 tidak memengaruhi IHSG. Hal ini karena adanya faktor diluar ekonomi yang menyebabkan indeks N225 melemah, sehingga tidak berdampak kepada IHSG.

H7: The Fed berpengaruh terhadap IHSG pada periode 2009-2019. 
Kenaikan indeks STI merupakan pertanda jika perekonomian Singapura membaik, akan meningkatkan IHSG karena adanya peningkatan kegiatan ekspor dan impor yang membuat pasar modal di Indonesia meningkat. Selaras dengan teori contagion effect menjelaskan bahwa keadaan ekonomi suatu negara akan berakibat pada negara lain. Riset yang telah dilakukan Desfiandi et al. (2017), Lailia et al. (2014), Tarigan et al. (2015), dan Triyono et al. (2016) memberikan hasil STI memengaruhi secara positif kepada IHSG. Hal ini karena letak negara Singapura dengan Indonesia berdekatan, sehingga cenderung memiliki investor yang sama, sehingga memiliki perilaku investor yang sama. Namun riset oleh Pamungkas \& Darmawan (2018) memberikan hasil IHSG dipengaruhi secara negatif oleh STI. Hal tersebut dikarenakan meningkatnya kebutuhan properti di Singapura, sehingga investasi pada sektor tersebut dinilai sangat menjanjikan dengan keuntungan yang cukup tinggi daripada berinvestasi di Indonesia. Riset oleh Candradewi \& Yasa (2018) memberikan hasil IHSG tidak dipengaruhi oleh STI. Hal ini bisa disebabkan karena ketidakseragaman naik-turunnya indeks STI dengan IHSG pada tahun 2012 hingga 2016. Ketidakseragaman ini terjadi karena pergerakan naik-turunnya IHSG di BEI lebih fluktuatif jika dibandingkan dengan STI yang cenderung tetap.

H8: Indeks STI berpengaruh terhadap IHSG pada periode 2009-2019.

\section{METODE PENELITIAN}

Penelitian ini adalah penelitian kulitatif kausalitas, riset ini dilaksanakan untuk membuktikan bahwa apakah ada dampak variabel independen yaitu pengaruh indikator makroekonomi dan faktor indeks global terhadap variabel dependen yaitu IHSG. Pada penelitian ini variabel yang akan diteliti sebagai variabel sebab (independen) yaitu IHSG, dan variabel yang merupakan akibat (dependen) yaitu variabel kurs, inflasi, JUB, BI Rate, The Fed, indeks SSEC, indeks Nikkei 225 dan indeks STI. Teknik analisis data yang digunakan dalam riset ini adalah regresi linier berganda. Analisis data menggunakan software SPSS versi 18. Sebelum melakukan pengujian hipotesis, terlebih dahulu dilakukan uji asumsi klasik. Pengujian ini dilakukan untuk menguji validitas dari data sekunder yang diperoleh. Sumber data yang diperoleh pada riset ini tidak langsung, yaitu data dari website Badan Pusat Statistik (BPS) yaitu www.bps.go.id, data kurs periode 2009-2019 didapatkan melalui website Bank Indonesia yaitu www.bi.go.id, data indeks Shanghai Composite Index, Nikkei 225, Strait Times Index dan IHSG diakses melalui website Yahoo Finance yaitu www.finance.yahoo.com, dan data suku bunga The Fed periode 2009-2019 diambil dari website New York Fed yaitu https://apps.newyorkfed.org/. Populasi pada riset ini merupakan harga penutupan (closing price) yang tercantum dalam website harga saham bulanan dan masuk dalam perhitungan IHSG selama Januari 2009 sampai Desember 2019. Sampel yang digunakan merupakan keseluruhan data, artinya seluruh populasi yang didapatkan untuk dijadikan sampel sejumlah 132 (data closing price indeks saham bulanan selama Januari 2009 - Desember 2019).

\section{HASIL DAN PEMBAHASAN}

\section{Hasil Uji Asumsi Klasik}

Dapat diketahui dari tabel 1, hasil uji normalitas dengan Kolmogorov Smirnov setiap variabel menunjukkan hasil Aymp. Sig. 2-tailed lebih dari 0,05 maka data residual telah terdistribusi normal. Pada tabel 1, dapat diketahui hasil uji multikolinieritas, hasil memberikan nilai tollerance seluruh variabel bebas gejala multikolinieritas, yaitu nilainya lebih besar atau sama dengan nilai 0.10. Kemudian, pada nilai VIF sudah memenuhi kriteria yaitu memberikan hasil nilai yang kurang dari 10 . Maka tidak adanya korelasi antar variabel dan model regresi tidak terdapat multikolinieritas.

Kemudian hasil pengujian autokorelasi pada tabel 1 dengan Durbin- Watson (D-W test), hasilnya telah ditemukan du senilai 1,8475 serta nilai DW senilai 2,009. Nilai D-W berada diantara nilai du dan 4-du yaitu $1,8475<2,009<2,1525$ memberikan hasil bahwa tidak terdapat autokorelasi yang positif atau negatif, dan tidak terjadi autokorelasi pada riset ini. Hasil pengujian heterokedastisitas pada tabel 1 menggunakan metode uji glejser memberikan hasil bahwa nilai signifikansi setiap variabel lebih dari 0,05 sehingga model regresi tidak terjadi heterokesdastisitas. Hasil pengujian linieritas pada tabel 1 dengan uji Lagrange Multiplier dari nilai $\mathrm{R}^{2}$ senilai 0.508 dengan $\mathrm{n}=109$, sehingga nilai $\mathrm{c}^{2}$ hitung 
Sebtian Dwi Prahesti \& R.A. Sista Paramita. Pengaruh Indeks SSEC, N225, STI, dan Faktor Makroekonomi terhadap IHSG

adalah 63,22 $(109 \times 0,508)$, kemudian besarnya nilai $\mathrm{c}^{2}$ tabel dengan $\mathrm{df}=100$ yaitu sebesar 124,34. nilai $\mathrm{c}^{2}$ hitung hasilnya lebih kecil dari nilai $\mathrm{c}^{2}$ tabel, telah sesuai kriteria jika besarnya nilai $\mathrm{c}^{2}$ hitung lebih kecil dari $\mathrm{c}^{2}$ tabel maka model yang tepat untuk digunakan adalah model linier. Berdasarkan tabel 2, diperoleh model persamaan (8).

$\mathrm{IHSG}=0,009-0,670$ Kurs $+0,531 \mathrm{STI}+\mathrm{e}$

Tabel 1.

HASIL UJI ASUMSI KLASIK

\begin{tabular}{lclcc}
\hline \multicolumn{1}{c}{ Uji Asumsi Klasik } & Dasar Pengambilan Keputusan & & Hasil Uji & \\
\hline Uji Normalitas & $>0,05$ & & 0,418 & \\
Uji Multikolonieritas & tolerance $>0,10$ dan VIF $<10$ & & Tolerance & VIF \\
& & Kurs & 0,642 & 1,558 \\
& & Inflasi & 0,905 & 1,104 \\
& & JUB & 0,909 & 1,100 \\
& & SSEC & 0,717 & 1,394 \\
& & N225 & 0,671 & 1,490 \\
& & STI & 0,474 & 2,109 \\
& & BI Rate & 0,483 & 2,070 \\
Uji Autokolerasi & The Fed & 0,530 & 1,888 \\
Uji Heteroskedastisitas & & & $1,8475<2,009<2,1525$ & \\
& & Kurs & .761 & \\
& & Inflasi & .132 & \\
& & JUB & .548 & \\
& & SSEC & .296 & \\
& & N225 & .371 & \\
Uji Linearitas & & STI & .595 \\
& & BI Rate & .941 & \\
& & The Fed & .366 \\
\hline
\end{tabular}

Sumber: Output SPSS (data diolah)

Dari kedelapan variabel riset terdapat dua variabel yang memberikan pengaruh signifikan terhadap variabel dependen yaitu variabel STI $\left(\mathrm{X}_{8}\right)$ dan Kurs $\left(\mathrm{X}_{1}\right)$. Berdasarkan persamaan regresi berganda dapat dijelaskan bahwa nilai konstanta sebesar 0,009 berarti bahwa jika nilai indeks STI dan kurs konstan, atau sama dengan nol, maka nilai IHSG adalah 0,009, sedangkan kurs yang memiliki nilai 0,670 berarti bahwa jika nilai kurs meningkat 1 satuan, maka nilai IHSG akan mengalami kenaikan sebesar -0,670. Hasil pengujian uji F pada tabel 2, memberikan hasil signifikansi F hitung sebesar 0,000 lebih kecil daripada tingkat signifikansi 0,005. Artinya, variabel independen yaitu kurs, inflasi, jumlah uang beredar, BI Rate, The Fed, indeks SSEC, indeks Nikkei 225, dan indeks STI secara bersama-sama berpengaruh terhadap variabel dependen yaitu Indeks Harga Saham Gabungan (IHSG). Berdasarkan tabel 2, bahwa nilai t hitung pada variabel kurs senilai $-4,007$ dengan signifikansi 0,000, sehingga kurs memengaruhi IHSG. Besarnya nilai t hitung variabel inflasi sebesar $-1,635$ dengan signifikansi 0,105 , hasil nilai signifikansi tersebut lebih besar dari 0,05 maka inflasi tidak memberikan pengaruh kepada IHSG. Nilai t hitung variabel jumlah uang beredar senilai -1,841 dengan signifikansi 0,69 , sehingga jumlah uang beredar tidak memberikan pengaruh apapun terhadap IHSG. Nilai t hitung variabel BI Rate senilai -0,244 dengan signifikansi 0,808, sehingga BI Rate tidak memberikan pengaruh kepada IHSG.

Nilai t hitung variabel The Fed senilai -0,56 dengan signifikansi 0,956, sehingga The Fed tidak memberikan pengaruh kepada IHSG. Nilai t hitung variabel indeks SSEC senilai -0,102 dengan signifikansi 0,919, dapat diketahui indeks SSEC tidak memberikan pengaruh kepada IHSG. Nilai t hitung variabel indeks N225 senilai 0,571 dengan signifikansi 0,569, indeks Nikkei 225 tidak memberikan pengaruh kepada IHSG. Nilai t hitung pada variabel STI senilai 5,396 dengan signifikansi 0,000 , sehingga indeks STI memberikan pengaruh terhadap IHSG. Berdasarkan tabel 2, hasil pengujian koefisien determinasi memberikan output bahwa besarnya adjusted $R^{2}$ sebesar 0,547 atau 54,7\% maka 
variabel independen yaitu kurs, inflasi, jumlah uang beredar, suku bunga BI Rate, suku bunga The Fed, indeks SSEC, indeks Nikkei 225 dan indeks STI dalam riset mampu menjelaskan variabel dependen yaitu Indeks Harga Saham Gabungan (IHSG) sebesar 54,7\%, kemudian 45,3\% dijelaskan oleh variabel lain yang tidak digunakan dalam penelitian ini seperti variabel indeks saham global lainnya KLSE Candradewi \& Yasa (2018), KOSPI Kusumawati \& Asandimitra (2017), Hangseng Wibowo et al. (2016), serta faktor makroekonomi yang tidak diteliti pada riset ini seperti PDB Arif (2013), Net Ekspor Sari \& Purwohandoko (2019), LIBOR Yustisia (2016). Nilai R koefisien korelasi sebesar 0,762, sehingga kekuatan hubungan antara variabel independen terhadap variabel dependen sebesar 76,2\%.

Tabel 2.

HASIL UJI HIPOTESIS

\begin{tabular}{lcccccc}
\hline & B & Std. Error & T & Sig. & R & Adjusted R Square \\
\hline (Constant) & .009 & .019 & .481 & .632 & & \\
Kurs & -.670 & .167 & -4.007 & .000 & & \\
Inflasi & -.041 & .025 & -1.635 & .105 & & \\
JUB & -.532 & .289 & -1.841 & .069 & & \\
BI Rate & -.003 & .010 & -.244 & .808 & & \\
The FED & $-3.891 \mathrm{E}-5$ & .001 & -.056 & .956 & \\
SSEC & -.005 & .050 & -.102 & .919 & \\
N225 & .039 & .068 & .571 & .569 & & \\
STI & .531 & .098 & 5.396 & .000 & & \\
Uji Statistik F & & & & 0.000 & 0,762 & 0,547 \\
Uji Koefisien & & & & & & \\
Determinasi & & & & & & \\
\hline Suri
\end{tabular}

Sumber: Output SPSS (data diolah)

\section{Pengaruh Kurs terhadap Indeks Harga Saham Gabungan (IHSG)}

Berdasarkan hasil analisis menunjukkan bahwa kurs memberikan hubungan negatif dan signifikan pada periode 2009 -2019. Kurs merupakan cerminan dari tingkat penawaran dan permintaan atas mata uang dalam negeri terhadap mata uang asing. Nilai kurs dari tahun 2009 - 2019 dapat diamati apabila nilai kurs berubah naik turun setiap tahunnya, hal ini mengakibatkan sulitnya perusahaan dalam melakukan perencanaan usahanya termasuk bagi para produsen yang melakukan impor bahan baku atau memperjualkan barangnya ke luar negeri. Besarnya nilai kurs cenderung mengalami kenaikan sehingga apabila nilai kurs mengalami depresiasi, bagi para investor akan memikirkan bahwa keadaan ekonomi Indonesia tidak baik. Saat penilaian perekonomian memburuk, investor menjual saham yang dimilikinya untuk mengurangi risiko yang besar. Aksi menjual seluruh saham ini tentunya akan berdampak pada melemahnya IHSG (Syarif \& Asandimitra, 2015). Seiring dengan teori random walk yang menjelaskan bahwa harga saham bergerak secara random, peregerakan saham ini dipengaruhi oleh bagaimana investor menanggapi adanya berita tentang kurs rupiah terhadap dollar. Investor pada instrumen investasi saham, selama periode penelitian mayoritas merupakan investor asing, ketika rupiah melemah maka harga pada portofolio di IHSG menjadi relatif lebih murah bagi investor asing. Sehingga investor asing akan memilih menginvestasikan uangnya terhadap mata uang dollar karena beranggapan bahwa kenaikan dollar akan menguat di masa yang akan datang. Hal tersebut membuat investor asing meningkatkan investasinya pada mata uang dollar (Subiantoro et al., 2018). Implikasi praktis pada penelitian ini sebaiknya investor memperhatikan informasi kurs, karena hasil penelitian ini variabel kurs memberikan pengaruh kepada IHSG. Maka kurs rupiah terhadap dollar apabila mengalami kenaikan dan penurunan akan memberikan dampak terhadap IHSG dan apabila investor mengamati nilai kurs, akan mendapatka informasi yang signifikan terkait IHSG, karena kurs akan menyediakan informasi dalam memprediksi IHSG.

\section{Pengaruh Inflasi terhadap Indeks Harga Saham Gabungan}

Berdasarkan hasil analisis statistik memberikan hasil bahwa perubahan nilai inflasi tidak memberikan pengaruh terhadap IHSG pada periode 2009-2019. Peningkatan harga yang meninggi tidak hanya memberikan dampak buruk pada kegiatan ekonomi, tetapi juga kesejahteraan individu dan masyarakat. 
Sebtian Dwi Prahesti \& R.A. Sista Paramita. Pengaruh Indeks SSEC, N225, STI, dan Faktor Makroekonomi terhadap IHSG

Inflasi tinggi tidak akan memberikan kinerja ekonomi yang baik. Kenaikan biaya yang drastis dan berlangsung lama membuat kegiatan produksi tidak menguntungkan (Yustisia, 2016). Penurunan keuntungan perusahaan mengakibatkan sebagian laba perusahaan yang akan dibagikan kepada investor juga mengalami penurunan akan berdampak pada investor tidak tertarik pada saham perusahaan, dapat memengaruhi pada penurunan IHSG. Berdasarkan hasil analisis statistik memberikan hasil perubahan tingkat inflasi yang tidak memberikan pengaruh apapun kepada IHSG. Hasil ini karena selama periode penelitian angka perubahan tingkat inflasi cukup rendah sehingga informasi tingkat inflasi tidak secara langsung menjadi pertimbangan investor dalam mengambil keputusan investasi (Syarif \& Asandimitra, 2015). Inflasi yang terjadi pada periode penelitian, tidak sampai menyentuh angka 10\%, Menurut (Desfiandi et al., 2017) menyatakan bahwa inflasi ringan (di bawah angka 10\%) tidak mampu memengaruhi pasar modal. Inflasi yang ringan tidak begitu mengganggu perekonomian Indonesia, dengan begitu tingkat inflasi ini tidak secara langsung memengaruhi keputusan investor untuk melakukan investasi dalam bentuk saham pada Bursa Efek Indonesia. Dalam hasil penelitian ini, inflasi tidak memengaruhi IHSG, hal itu dapat disebabkan karena perusahaan tidak beranggapan kenaikan inflasi menjadi hambatan bagi perusahaan dalam menjalankan bisnisnya, perusahaan masih mampu melakukan bisnisnya atau mengendalikan inflasi untuk memaksimalkan profitabilitas. Ketika inflasi naik menjadi 10\%, kebijakan Bank Indonesia akan meningkatkan suku bunga BI Rate untuk menstabilkan perekonomian, sehingga para investor lebih memilih menginvestasikan dananya kepada pasar modal, dan dapat memengaruhi penurunan IHSG. Namun apabila inflasi masih di bawah $10 \%$ belum mampu memengaruhi pasar modal. Hasil riset ini tidak sejalan dengan random walk theory dan hipotesis menyatakan inflasi berpengaruh terhadap IHSG, sehingga informasi kenaikan maupun penurunan inflasi tidak terlalu mperhatikan oleh investor, investor cenderung mengamati informasi selain IHSG. Implikasi praktis dalam penelitian ini adalah sebaiknya investor tidak menjadikan inflasi sebagai acuan atau informasi untuk dipertimbangkan dalam pengambilan keputusan ketika ingin berinvestasi saham di pasar modal Indonesia jika tingkat inflasi masih berada di bawah $10 \%$, karena berdasarkan hasil penelitian ini, pada periode 2009-2019 inflasi di Indonesia masih di bawah $10 \%$. Jika investor mengamati inflasi yang ringan, investor tidak akan mendapatkan hasil yang signifikan terkait IHSG karena inflasi tidak menyediakan informasi dalam memprediksi pertumbuhan IHSG.

\section{Pengaruh Jumlah Uang Beredar terhadap Indeks Harga Saham Gabungan}

Berdasarkan hasil analisis statistik menunjukkan bahwa perubahan variabel jumlah uang beredar tidak berpengaruh terhadap perubahan IHSG pada periode 2009-2019. Pada penelitian ini, M2 merupakan jumlah uang beredar adalah salah satu variabel sektor moneter yang dianggap penting dan essensial. Dalam suatu penelitian JUB dinyatakan sebagai indikator yang dapat memberikan sinyal baik bagi investor dalam mengambil keputusan berinvestasi. Menurut Samuelson dan Nordhaus (2004) dalam Wibowo et al. (2016), uang adalah sesuatu yang berguna sebagai alat tukar yang diterima pada masyarakat umum. Uang juga merupakan suatu alat pembayaran, mata uang dan cek yang digunakan apabila kita membeli sesuatu. Apabila jumlah uang beredar meningkat, maka berdampak pada kenaikan harga saham. Hal tersebut disebabkan karena ketika jumlah uang beredar mengalami peningkatan, maka masyarakat akan lebih memilih melakukan investasi. Ketika para investor melakukan transaksi atas saham serta menyimpan dananya pada instrumen saham, maka akan memberikan dampak pada IHSG. Dari data penelitian dapat diketahui bahwa perubahan nilai JUB tertinggi sebesar 38,7\% dan penurunan paling drastis adalah $-51 \%$, pada periode 2009-2019, namun hasil penelitian memberikan hasil bahwa jumlah uang beredar tidak memberikan pengaruh apapun terhadap IHSG, artinya, kenaikan maupun penurunan atas informasi jumlah uang beredar tidak mampu memberikan informasi untuk laju IHSG. Masyarakat cenderung menggunakan uangnya untuk alat pembayaran atas kebutuhan konsumsi, dalam transaksi pembelian atau membayar hutang, dan melakukan investasi di pasar uang daripada berinvestasi di saham. Riset ini menemukan sebaiknya investor tidak memperhatikan jumlah uang beredar sebagai informasi melakukan investasi di pasar modal, karena hasil dari penelitian ini menyatakn bahwa jumlah uang beredar tidak berpengaruh terhadap IHSG.

\section{Pengaruh BI Rate terhadap Indeks Harga Saham Gabungan (IHSG)}

Hasil analisis statistik menunjukkan bahwa variabel suku bunga BI Rate tidak memberikan pengaruh apapun terhadap indeks harga saham gabungan pada periode 2009-2019. Hasil penelitian ini tidak selaras dengan hipotesis yang menyatakan bahwa suku bunga BI Rate berpengaruh terhadap IHSG, 
namun hasil penelitian ini selaras dengan penelitian Triyono et al. (2016) yang memberikan hasil suku bunga BI Rate tidak berpengaruh terhadap IHSG. Kenaikan tingkat bunga memberi peningkatan pada beban bunga. Emiten yang memiliki tingkat leverage yang tinggi akan mendapatkan efek sangat berat pada peningkatan tingkat bunga. Perubahan kebijakan atas besarnya BI Rate juga dapat memengaruhi besar bungan Sertifikat Bank Indonesia atau besar bunga deposito dan tabungan. Pada periode penelitian tahun 2009-2019 memberikan hasil bahwa BI Rate tidak berpengaruh terhadap IHSG, artinya kenaikan maupun penurunan suku bunga BI Rate tidak membuat investor memindahkan investasinya dari deposito atau SBI berpindah ke investasi pasar modal seperti saham, hal ini dapat disebabkan oleh tingkat risiko pada investasi SBI, atau deposito lebih rendah, atau bebas risiko daripada berinvestasi pada saham. Hasil riset ini sebaiknya investor tidak menggunakan BI Rate sebagai pedoman atau informasi ketika ingin melakukan investasi pada instrumen saham sebab menurut hasil penelitian ini BI Rate tidak memberikan pengaruh terhadap IHSG karena BI Rate bukan parameter instrumen investasi yang diperhatikan masyarakat. Saat BI Rate meningkat maupun menurun, tidak memberikan pengaruh terhadap IHSG.

\section{Pengaruh The Fed terhadap Indeks Harga Saham Gabungan (IHSG)}

Berdasarkan hasil analisis statistik menunjukkan bahwa variabel The Fed tidak memberikan pengaruh apapun terhadap IHSG pada periode 2009-2019. Hasil penelitian tidak selaras dengan hipotesis bahwa The Fed memberikan pengaruh kepada IHSG. Tetapi hasil riset ini sesuai dengan riset oleh Syarif \& Asandimitra (2015) bahwa The Fed tidak memberikan pengaruh kepada IHSG. Negara Amerika Serikat negara maju yang memiliki banyak investor bermodal besar, sehingga tentu banyak investor yang mendasarkan keputusan investasinya mengikuti perekonomian Amerika Serikat. Hal ini tentunya banyak para investor yang melakukan pengambilan keputusan dengan memantau informasi ekonomi Amerika. Pada penelitian yang dilakukan oleh Syarif \& Asandimitra (2015) pada periode 2005-2014 (10 tahun) memberikan hasil bahwa suku bunga The Fed tidak berpengaruh pada IHSG, namun penelitian yang dilakukan oleh Misgayanti \& Zuhroh (2009) pada periode 2006-2008 (2 tahun) memberikan hasil bahwa suku bunga The Fed berpengaruh terhadap IHSG. Dari pernyataan di atas, dapat diketahui bahwa bagi investor yang menginvestasikan dananya pada pasar modal dalam jangka panjang 10 tahun atau lebih tidak perlu memperhatikan suku bunga The Fed dalam mengambil keputusan untuk berinvestasi di pasar modal, namun untuk para investor yang senang melakukan investasi dalam jangka pendek (trader) sebaiknya memperhatikan suku bunga The Fed dalam melakukan investasi di pasar modal. Hasil riset ini adalah sebaiknya para investor tidak menjadikan suku bunga The Fed sebagai pedoman atau informasi ketika ingin berinvestasi saham dalam jangka panjang seperti pada periode penelitian ini 2009-2019 (11 tahun), karena investor tidak akan mendapatkan informasi yang signifikan terkait prediksi laju IHSG. Namun apabila investor melakukan investasi saham dalam jangka waktu pendek (2 tahun) seperti pada jurnal Misgayanti \& Zuhroh (2009) sebaiknya memperhatikan suku bunga The Fed sebagai acuan atau bahan pertimbangan dalam berinvestasi saham, karena akan memberikan hasil yang signifikan terkait prediksi laju IHSG.

\section{Pengaruh Indeks SSEC terhadap Indeks Harga Saham Gabungan (IHSG)}

Berdasarkan hasil analisis menunjukkan bahwa perubahan variabel indeks SSEC tidak berpengaruh terhadap IHSG pada periode 2009-2019. Indeks SSEC merupakan indeks saham dari negara Cina, di mana dapat diketahui bahwa negara Cina merupakan negara asal impor Indonesia peringkat satu, dan negara tujuan ekspor Indonesia peringkat satu, hal ini menunjukkan bahwa perekonomian negara Cina dapat memengaruhi perekonomian Indonesia, namun pada hasil penelitian ini pada periode 2009-2019 indeks SSEC tidak memberikan pengaruh apapun terhadap IHSG. Hal ini dapat terjadi karena adanya faktor lain diluar faktor ekonomi, indeks harga saham tidak hanya terpengaruhi oleh perekonomian saja, dapat juga bencana alam, keadaan politik suatu negara yang terjadi di negara Cina menyebabkan negara tersebut mengalami resesi atau penurunan dan bursa sahamnya ikut melemah dan tidak memberikan dampak terhadap IHSG. Tidak berpengaruhnya indeks SSEC terhadap IHSG dapat disebabkan karena adanya konflik internal pada Cina atau bencana alam di Cina, bahkan bencana yang terjadi di Cina akibat kelalaian manusia. Konflik yang terjadi adalah adanya konflik internal atas Xinjiang. Salah satu provinsi sebelah Barat Laut Cina yang sering mengalami beda pendapat atas kepentingan politik pemerintah Beijing yang mayoritas Cina Han. Xinjiang merupakan salah satu konflik internal yang 
Sebtian Dwi Prahesti \& R.A. Sista Paramita. Pengaruh Indeks SSEC, N225, STI, dan Faktor Makroekonomi terhadap IHSG

cukup besar di Cina karena merupakan konflik tersebut merupakan bentuk konflik antar etnis yang kemudian berkembang menjadi gerakan separatisme (Karisma, 2017). Konflik internal ini merupakan konflik yang dapat menyebabkan bursa saham di Cina menurun namun tidak memberi dampak terhadap IHSG. Kemudian pada tanggal 7 September 2012, Sungai Yangtze airnya menjadi kotor tercemar karena banyaknya pabrik yang telah membuang limbah kimia di aliran sungai ini. Akibatnya terjadi infeksi bakteri E. Coli merebak dan penyakit disentri mengalami peningkatan drastis dan hepatitis sebanyak 50\% dari penduduk Cina. Beberapa hal di atas menyebabkan penurunan atas bursa Cina yang tidak memberikan dampak terhadap IHSG. Implikasi praktis dari hasil riset yang telah dilakukan adalah bahwa investor tidak menjadikan indeks SSEC untuk pedoman atau pertimbangan dalam pengambilan keputusan apabila melakukan investasi pada instrumen saham, karena Indeks SSEC tidak memberikan pengaruh apapun terhadap IHSG. Saat indeks SSEC mengalami peningkatan maupun penurunan tidak mampu memberikan dampak terhadap IHSG.

\section{Pengaruh indeks Nikkei 225 terhadap Indeks Harga Saham Gabungan (IHSG)}

Berdasarkan hasil analisis menunjukkan bahwa perubahan variabel indeks Nikkei 225 tidak memberikan pengaruh apapun terhadap IHSG pada periode 2009-2019. Hasil tidak selaras dengan hipotesis, Indeks Nikkei 225 berpengaruh terhadap IHSG. Namun hasil riset sesuai yang dilakukan oleh Sari \& Purwohandoko (2019), Wibowo et al. (2016), dan Zabidi \& Asandimitra (2018) yang memberikan hasil bahwa indeks Nikkei 225 tidak berpengaruh pada IHSG. Negara Jepang merupakan negara ekspor non migas tujuan Indonesia peringkat ketiga dan negara impor non migas asal peringkat kedua. Hal ini menunjukkan keadaan perekonomian Jepang dapat memengaruhi perekonomian Indonesia. Namun perekonomian Jepang tidak mampu memberikan pengaruh terhadap pasar modal Indonesia, karena hasil penelitian ini menyatakan bahwa indeks Nikkei 225 tidak memberikan pengaruh terhadap IHSG. Tidak berpengaruhnya dapat disebabkan oleh faktor diluar ekonomi. Faktor lain diluar ekonomi juga dapat memberikan pengaruh suatu harga saham, seperti bencana alam yang terjadi di negara Jepang yang dapat menurunkan indeks Nikkei 225 namun tidak memberikan pengaruh terhadap IHSG. Tercatat pada bulan Mei 2011, terjadi gempa, tsunami dan krisis nuklir yang menyebabkan perekonomian Jepang menyusut sebesar 3,7\%. Bencana gempa bumi berkekuatan 9 richter dan tsunami besar pada negara Jepang dan menimbulkan adanya krisis nuklir karena rusaknya PLTN Fukushima. Hal itu mengakibatkan kondisi negara Jepang berada pada titik terburuk, serta adanya rantai suplai yang bermasalah disebabkan bencana yang telah mengganggu proses produksi. Kemudian pada Desember 2019 Jepang melaporkan keterlambatan ekonominya, Jepang mengalami penurunan PDB sebesar 6,3\%, hal ini dikarenakan adanya penyebaran kasus corona yang berasal dari Wuhan, Cina. Penyebaran virus tersebut dianggap menyebabkan penurunan pemasukan anggaran Jepang dan pembebanan konsumsi domestik, virus ini juga dianggap sebagai pandemi global karena total pasien terinfeksi corona di seluruh dunia menjadi 70.400 orang. Hal ini menyebabkan bursa saham Jepang mengalami penurunan, namun bursa saham Indonesia tidak terkena dampaknya karena tercatat virus corona pertama kali menyebar ke Indonesia pada bulan Maret 2020. Riset memberikan hasil bahwa investor tidak perlu memperhatikan indeks Nikkei 225 sebagai pedoman atau sarana pengambilan keputusan apabila ingin berinvestasi pada instrumen saham, karena berdasarkan hasil penelitian indeks Nikkei 225 tidak memberikan pengaruh apapun terhadap IHSG. Ketika indeks Nikkei 225 mengalami kenaikan maupun penurunan tidak memberikan dampak terhadap IHSG.

\section{Pengaruh indeks STI terhadap Indeks Harga Saham Gabungan (IHSG)}

Hasil penelitian ini menunjukkan bahwa indeks Strait Times memberikan berpengaruh terhadap IHSG, hal ini menunjukkan bahwa indeks STI memberikan pengaruh yang signifikan pada periode 2009-2019. Hubungan antara indeks STI dengan IHSG menunjukkan bahwa para investor sangat memperhatikan indeks STI jika hendak berinvestasi di pasar modal. Indeks Strait Times merupakan indeks saham negara Singapura, di mana dapat diketahui negara Singapura merupakan negara impor non migas asal Indonesia peringkat ke 4, dan negara ekspor tujuan ndonesia peringkat ke 5 , hal ini menunjukkan bahwa perekonomian Singapura memengaruhi perekonomian Indonesia. Lokasi bursa saham yang berdekatan terkadang mempunyai kesamaan investor, sehingga apabila terjadi pergerakan indeks saham di bursa lain, IHSG ikut berubah nilainya. Negara Singapura adalah negara kawasan Asia Tenggara yang sangat dekat dengan negara Indonesia, dan termasuk negara maju, sehingga perekonomiannya berdampak pada perekonomian Indonesia. Kegiatan ekspor dan impor antara Indonesia dengan Singapura dapat 
memberikan dampak pertumbuhan ekonomi antar dua negara, karena adanya arus masuk kedalam investasi melalui pasar modal. Hal ini memudahkan bagi investor dalam berinvestasi, menyebabkan pergerakan indeks STI berpengaruh terhadap IHSG karena bursa negara maju yang memiliki kapasitas besar dapat memengaruhi bursa saham negara berkembang. Riset ini menemukan bahwa sebaiknya investor menjadikan indeks STI sebagai pedoman atau bahan pengambilan keputusan apabila ingin berinvestasi saham, kareana berdasarkan hasil penelitian ini indeks STI memberikan pengaruh terhadap IHSG

\section{KESIMPULAN}

Hasil temuan yang didapatkan dari penelitian ini adalah faktor yang memengaruhi IHSG adalah variabel kurs dan STI, sedangkan variabel inflasi, jumlah uang beredar, BI Rate, The Fed, indeks SSEC dan indeks Nikkei 225 tidak memberikan pengaruh kepada IHSG. Bagi investor yang akan berinvestasi pada instrumen saham, sebaiknya memperhatikan pergerakan perubahan kurs dan indeks STI, karena kedua faktor tersebut dapat memengaruhi pergerakan Indeks Harga Saham Gabungan. Dengan memperhatikan pergerakan kurs dan indeks STI, investor dapat memprediksi pergerakan IHSG dalam pengambilan keputusan investasi. Diharapkan pemerintah untuk memantau pergerakan kurs dan menjaga kestabilan nilai kurs untuk mempertahankan kinerja IHSG. Yang kedua variabel indeks STI memiliki pengaruh terhadap IHSG, maka diharapkan pemerintah memantau kinerja indeks STI dan perekonomian Singapura dalam memempertahankan kinerja IHSG. Penelitian selanjutnya disarankan menggunakan variabel indeks saham global lainnya KLSE Candradewi \& Yasa (2018), KOSPI Kusumawati \& Asandimitra (2017), Hangseng Wibowo et al. (2016), serta faktor makroekonomi yang tidak diteliti pada riset ini seperti PDB Arif (2013), Net Ekspor Sari \& Purwohandoko (2019), LIBOR Yustisia (2016).

\section{DAFTAR PUSTAKA}

Adanti, W. A. (2017). Analisis Pengaruh Faktor Fundamental Makro Ekonomi terhadap Indeks Harga Saham Gabungan (IHSG). Jurnal Ilmiah Aset, 19(2), 161-172.

Arif, D. (2013). Pengaruh Produk Domestik Bruto, Jumlah Uang Beredar, Inflasi, dan BI Rate Terhadap Indeks Harga Saham Gabungan di Indonesia Periode 2007-2013. Jurnal Ekonomi Bisnis, 19(3).

Bery, D., \& Worokinasih, S. (2018). Pengaruh Indeks Harga Saham Global Terhadap Indeks Harga Saham Gabungan (IHSG) (Studi pada Bursa Efek Indonesia Periode 2014-2017). Jurnal Administrasi Bisnis, 64(1).

Candradewi, N. M. S., \& Yasa, G. W. (2018). Pengaruh SBI, Kurs Rupiah, STI, SET, dan KLSE pada Indeks Harga Saham Gabungan. E-Jurnal Akuntansi, 23, 2359. https://doi.org/10.24843/EJA.2018.v23.i03.p28

Desfiandi, A., Desfiandi, A., \& Ali, H. (2017). Composite Stock Price Index ( IHSG ) Macro Factor in Investment in Stock ( Equity Funds ). International Journal of Economics and Financial, 7(3), 534-536.

Jogiyanto. (2000). Teori Portofolio dan Analisis Investasi. Yogyakarta: BPFE UGM.

Karisma, G. (2017). Konflik Etnis di Xinjiang: Kebijakan Monokultural dan Kepentingan Negara China Terhadap Keutuhan Wilayah. SOSIOLOGI: Jurnal Ilmiah Kajian Ilmu Sosial Dan Budaya, 19(1), 41-52. https://doi.org/10.1017/CBO9781107415324.004

Kusumawati, D. A., \& Asandimitra, N. (2017). Impact of Global Index , Gold Price and Macro Economic Variable for Indonesia Composite Index. Journal of Finance and Accounting, 8(2), $53-62$. 
Sebtian Dwi Prahesti \& R.A. Sista Paramita. Pengaruh Indeks SSEC, N225, STI, dan Faktor Makroekonomi terhadap IHSG

Lailia, H., Darminto, \& Hidayat, R. R. (2014). Pengaruh Tingkat Suku Bunga, Tingkat Inflasi, Nilai Kurs Dollar dan Indeks Strait Times Terhadap Indeks Harga Saham Gabungan (Studi Pada Bursa Efek Indonesia Periode Januari 2010-Juni 2013). Jurnal Administrasi Bisnis, 12(1), 1-10.

Misgayanti, \& Zuhroh, I. (2009). Pengaruh Suku Bunga Luar Negeri Federal Reserve (the Fed), Nilai Tukar Rupiah/Us \$ dan Inflasi Terhadap Indeks Harga Saham Gabungan di Bursa Efek Indonesia $\begin{array}{lllll}\text { Periode 2006-2008. Jurnal Ekonomi Pembangunan, } & \text { 7(1), } .\end{array}$ https://doi.org/10.22219/jep.v7i1.3580

Miyanti, G. A. D. A., \& Wiagustini, L. P. (2018). Pengaruh Suku Bunga The Fed, Harga Minyak Dan Inflasi Terhadap Indeks Harga Saham Gabungan (IHSG) di Bursa Efek Indonesia. E-Jurnal $\begin{array}{lllll}\text { Ekonomi Dan Bisnis Universitas } & 1261 .\end{array}$ https://doi.org/10.24843/eeb.2018.v07.i05.p02

Otorima, M., \& Kesuma, A. (2016). Pengaruh Nilai Tukar, Suku Bunga, Inflasi, Jumlah Uang Beredar Dan PDB Terhadap Indeks Harga Saham Gabungan (IHSG) Periode 2005-2015. Jurnal Terapan Manajemen Dan Bisnis, 2(2), 12-24.

Pamungkas, B. C., \& Darmawan, A. (2018). Pengaruh Nilai Tukar USD Dan Bursa Asean Terhadap Indeks Harga Saham Gabungan (IHSG) ( Studi pada Bursa Efek Indonesia Periode 2014 - 2016 ). Jurnal Administrasi Bisnis, 60(1), 73-81.

Samsul, M. (2015). Pasar Modal dan Manajemen Portofolio (2nd ed.). Jakarta: Erlangga.

Sari, D. N., \& Purwohandoko. (2019). Dampak Pengaruh Bursa Saham Global, Harga Emas Dunia dan Variabel Makroekonomi Terhadap Indeks Harga Saham Gabungan Periode 2009-2018. Jurnal Ilmu Manajemen, 7(3), 772-783.

Siregar, Y. P., Rosyetti, \& Kornita, S. E. (2014). Pengaruh Nilai Tukar, Inflasi dan Jumlah Uang Beredar Terhadap Indeks Harga Saham Gabungan (IHSG) di Bursa Efek Indonesia (BEI) Tahun 1994-2013. Jom Fekon, 1(2), 1-15.

Subiantoro, A. N., Topowijono, \& Sulasmiyati, S. (2018). Pengaruh Inflasi , BI Rate , Kurs USD / IDR , Indeks Shcomp , Dan Indeks Nikkei 225 Terhadap Indeks Harga Saham Gabungan ( IHSG ) ( Studi Pada Bursa Efek Indonesia Periode 2015-2017 ). Jurnal Administrasi Bisnis (JAB), 61(3), 198-206. Retrieved from administrasibisnis.studentjournal.ub.ac.id/index.php/jab/.../2614\%0A

Sukamto, S. W. (2016). Pengaruh Inflasi, Suku Bunga, dan Nilai Tukar Rupiah Terhadap Indeks Harga Saham Gabungan (IHSG) di Bursa Efek Indonesia. Jurnal Manajemen Bisnis, 6(2). https://doi.org/10.1017/CBO9781107415324.004

Suprihati. (2015). The Analysis of The Influence of Exchange Rate, SBI Interest Rate, Inflation Rate, Dow Jones Index And Nikkei 225 Index To IHSG. International Journal of Scientific Research and Education, 3(5), 3428-3442.

Syarif, M. M., \& Asandimitra, N. (2015). Pengaruh Indikator Makro Ekonomi dan Faktor Global Terhadap Indeks Harga Saham Gabungan (IHSG). Jurnal Studi Manajemen, 9(2), 142-156.

Tandelilin, E. (2008). Analisis Investasi dan Manajemen Portofolio. Yogyakarta: Kanisius.

Tarigan, R. D., Suhadak, \& Topowijono. (2015). Pengaruh Indeks Harga Saham Global Terhadap Indeks Harga Saham Gabungan ( IHSG ) Studi Pada Bursa Efek Indonesia ( Bei ) Periode 20112014. Jurnal Administrasi Bisnis, 24(1), 1-8.

Taufiq, M., \& Kefi, B. S. (2015). Pengaruh Inflasi, BI Rate dan Kurs Terhadap Indeks Harga Saham 
Gabungan. Jurnal Ekonomi Manajemen Akuntansi, 22(38). https://doi.org/10.1017/CBO9781107415324.004

Triyono, D., Indarto, \& Santoso, A. (2016). Analisis Pengaruh Indeks Harga Saham Asing dan Variabel Makroekonomi Indonesia Terhadap Indeks Harga Saham Gabungan (IHSG) di Bursa Efek Indonesia (Periode Januari 2013-Agustus 2015). Jurnal Riset Ekonomi Dan Bisnis, 9(3), 20-39.

Wibowo, F., Arifati, R., \& Raharjo, K. (2016). Analisis Pengaruh Tingkat Inflasi, Suku Bunga SBI, Nilai Tukar US Dollar Pada Rupiah, Jumlah Uang Beredar, Indeks DOw Jones, Indeks Nikkei 225, dan Indeks Hangseng Terhadap Pergerakan Indeks Harga Saham Gabungan (IHSG) Periode 2010-2014. Journal of Accounting, 2(2), 1689-1699. https://doi.org/10.1017/CBO9781107415324.004

Wismantara, S. Y., \& Darmayanti, N. P. A. (2017). Pengaruh Nilai Tukar, Suku Bunga dan Inflasi Terhadap Indeks Harga Saham Gabungan di Bursa Efek Indonesia. E-Jurnal Manajemen Unud, 6(8), 4391-4421.

Yustisia, N. (2016). Faktor-Faktor yang Memengaruhi Pergerakan Indeks Harga Saham Gabungan di Bursa Efek Indonesia. Jurnal Bisnis Dan Komunikasi, 3(2), 38-43.

Zabidi, I. I., \& Asandimitra, N. (2018). Pengaruh Inflasi, Kurs, Suku Bunga SBI, Dow Jownes, dan Nikkei 225 Terhadap Indeks Harga Saham Gabungan Pada Bursa Efek Indonesia Periode 20122016. Jurnal Ilmu Manajemen, 6(4), 468-476. 